УдК 81

\title{
ПРОБЛЕМЫ ЛИНГВИСТИКИ
}

DOI: $10.33184 /$ NYVB-2021-04-06.1

Мурясов Р.3. (д.ф.н., проф., БашГУ, г. Уфа)

МЕСТОИМЕНИЯ В НЕМЕЦКОМ И РУССКОМ ЯЗЫКАХ

В статье рассматривается вопрос о статусе местоимений в системе языка вообще и системе частей речи в частности. Сопоставительное изучение разрядов местоимений приводит $\kappa$ выявлению существенных количественных $u$ номенклатурных различий в их классификации.

Ключевые слова: статус местоимений в системе языка, разряды местоимений

The article touches upon the status of pronouns in the language system in general and the parts of speech system in particular. A comparative study of the pronouns categories results in the identification of significant quantitative and nomenclatural differences in their classification.

Keywords: the status of pronouns in the language system, the categories of pronouns

Статус местоимений в системе частей речи в индоевропейских языках всегда был предметом острых дискуссий в истории лингвистической науки. Одними лингвистами местоимения признаются как автосемантичная (знаменательная), другими языковедами отрицается их статус как части речи, третья группа лингвистов одну часть данного класса слов считает самостоятельной частью речи, другую часть «растворяет» в классе существительных, прилагательных и наречий.

В рамках данного доклада мы рассматриваем местоимения в немецком и русском языках. Латинский термин pгопотеn не охватывает весь функционально-семантический потенциал данной части речи, ср. pronomen «вместо имени». В некоторых современных вузовских и школьных грамматиках германских и романских языков (англ. pronoun, нем. Pronomen, фp. pronom и т.п.) этот термин заменяется обозначениями национальных языков, ср. нем. Pro-Form, Pro-Wörter, англ. pro-form, и т.п.). Причиной отказа 
от латинского грамматического термина состоит в том, что местоимения являются заменителями (заместителями) не только имен существительных, а и словосочетаний, предложений и целого дискурса. Так, нем. es, англ. it, фp. il/elle, русск. это, все это в дискурсе выступают в качестве заместителей единиц разного объема и сложности.

Противоречивое положение в системе языка занимают так называемые личные местоимения, а именно личные местоимения 1-го и 2-го лица ед. и мн. числа не заменяют какое-либо существительное или другое слово и выступают в качестве коммуникативно вариабельных величин: $я, m b l, ~ M b l, ~ b b l, ~ B b l$ могут обозначать любого участника коммуникации в зависимости от того, кто является автором или адресатом речи. Следовательно, по отношению к вышеперечисленным словам термин pronomen вообще не применим. Иначе обстоят дела с формами 3-го лица ед. числа (русск. он, она, оно, англ. he, she, it, фp. il / elle, нем. er, sie, es) и формами мн. числа (англ. they, русск. они, нем. sie), в которых родовые различия отсутствуют. Формы 3-го лица имеют антецедентные или постцедентные единицы. Кроме того, в русском и немецком они могут относиться как к одушевленным существам, так и неодушевленным предметам с учетом их родовой характеристики.

В русском и немецком языках представлены принципиально отличные подходы к анализируемому классу слов. В академической грамматике русского языка местоимения не рассматриваются как самостоятельная часть речи. В ней выделены местоимения-существительные [1, с. 531], «местоименные прилагательные, не называющие качества или свойства, а только указывающие на него (мой, тот, свой, каждый)» [1, с. 540].

В немецкой грамматической традиции также имеют место разные подходы к статусу местоимений. По отношению к другим частям речи можно указать на три группы местоимений: 1. субстантивные (личные, возвратные, безличные, взаимные), 2. адъективное (притяжательное), относящиеся как к субстантивным, 
так и к адъективным (указательные, неопределенные, отрицательные и вопросительные) [2, с. $121 ; 3]$.

В структурном отношении местоимения в немецком и русском языках распределены неравномерно. В обоих языках представлены простые, сложные и составные единицы, ср. простые: личные местоимения (нем. ich, du, er, sie, es, wir, ihr/sie, Sie; русск. я, ты, он, мы, вы, они); притяжательные местоимения (нем. mein, dein, ihr, unser, euer; русск. мой, твой, его, ее, наш, ваш, их); указательные местоимения (нем. der «этот», es «это», dieser, jener «Тот»; русск. тот, этот, такой и т.п.); вопросительные (нем. и русск. wer «кто», was «что»); возвратные (нем. sich, mich, dich, uns, euch; русск. себе, себя, собой); безличное (нем. es (es regnet «идет дождь»), в русском языке отсутствует); неопределенно-личные (нем. man; в русском языке отсутствует); сложные: указательные (нем. derjenige «тот», derselbe «тот же самый»; русск. тот-то, такой-то); отрицательные (нем. отсутствует; русск. никто, не́кого, ничто, не́чего); неопределенные (нем. jedermann; русск. ктонибудь, кто-то, кто-либо, кое-кто, некто, что-то, что-нибудь, что-либо, кое-что, нечто); составные: вопросительные (нем. was für ein «который, что за»; русск. что за); взаимные (русск. друг друга; нем. отсутствует); неопределенные (нем. irgendjemand «кто-то», sо etwas, so was «нечто подобное»).

Пестрая картина представлена в классификации разрядов (лексико-грамматических групп) местоимений как в рамках одного языка в трудах разных авторов и в двух сравниваемых языках.

Привожу классификации разрядов местоимений в немецком языке в грамматических исследованиях разных авторов.

Таблица 1

\section{Разряды местоимений в немецком языке}

Разряды местоимений

1.Личные

2.Притяжательные

3.Указа-

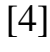

$+$

$+$

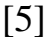

$+$

$+$

$+$
[6]

$+$

$+$

$+$
[7]

$+$

$+$
[8]

[9]

[10]

$+$

$+$

$+$ 
тельные

4.Относи-

тельные

5.Вопросительные

6.Определительные

7.Взаимные

8.Неопределенные

9.Возвратные

10.Безличное

11.Отрица-

тельные

12.Количественные

13.Собира-

тельные и

дистрибу-

тивные

14.Двойственного числа

15.Идентификационное

Таким образом, в немецких грамматиках единодушно выделены 4 разряда местоимений: личные, притяжательные, указательные и неопределенные. В некоторых исследованиях в один разряд объединены местоимения, квалифицируемые другими авторами как самостоятельные разряды. Так, О.И.Москальская включает в разряд личных местоимений также возвратные и взаимные, П.Айзенберг и Х.Глинц объединяют в один разряд вопросительные и относительные местоимения.

Таблица 2

\section{Разряды местоимений в русском языке}

\begin{tabular}{|c|c|c|c|c|c|c|c|c|}
\hline Автор & Личные & Возв & Вопр. & Указ. & Неопр & Отри & Притяж & Определи \\
\hline$[1]$ & + & + & + & - & + & - & - & - \\
\hline$\lceil 11]$ & + & + & + & + & + & + & + & + \\
\hline
\end{tabular}




\begin{tabular}{|l|l|l|l|l|l|l|l|l|}
\hline$[12]$ & + & - & + & + & + & + & + & + \\
\hline
\end{tabular}

В грамматиках по русскому языку некоторые разряды местоимений объединены в один класс, ср. Гр-60 (личные и возвратные), а в [11] и [12] вопросительные и относительные, в Гр80 [1] в один разряд объединены неопределенные и отрицательные местоимения.

Отсутствие строгой однозначной классификации разрядов местоимений как в немецком, так и в русском языках обусловлено поликатегориальностью некоторых единиц. Так, формально одна и та же единица в зависимости от синтаксической дистрибуции может выступать в роли единиц разных разрядов. Особенно текучи границы между вопросительными и относительными местоимениями.

Многозначность местоимений - явление широко распространенное, особенно, в немецком языке.

\section{ЛИТЕРАТУРА}

1. Русская грамматика. Т. І. Фонетика. Фонология. Ударение, Интонация, Словообразование. Морфология. М.: Изд-во «Наука», 1980.

2. Paul H. Deutsche Grammatik. Bd. 3. VEB Max Niemeyer Verlag. Halle (Saale), 1958.

3. Schendels E.I. Deutsche Grammatik. Morphologie. Syntax. Text. М.: Издво «Высшая школа», 1988.

4. Duden. Bd. 4. Die Grammatik. Dudenverlag. Mannheim. Leipzig. Wien. Zürich, 2005.

5. Helbig G., Buscha J. Deutsche Grammatik. Langenscheidt Verlag Enzyklopädie. Leipzig. Berlin. München. Wien. Zürich. New York, 1996.

6. Grundzüge einer deutschen Grammatik. Akademie-Verlag Berlin, 1981.

7. Eisenberg P. Grundriss der deutschen Grammatik. Verlag J.B.Metzler. Stuttgart. Weimar, 1994.

8. Glinz H.Grammatiken im Vergleich. Max Niemeyer Verlag. Tübingen, 1994.

9. Moskalskaja O.I. Grammatik der deutschen Gegenwartssprache. Moskau. Vysšaja škola, 1983.

10. Admoni Wl. Der deutsche Sprachbau. М.: Изд-во «Высшая школа», 1983.

11. Валгина Н.С., Розенталь Д.Э., Фомина М.И., Цапукевич В.В. Русский язык. М.: Изд-во «Высшая школа», 1966.

12. Грамматика русского языка. М.: Изд-во «Наука», 1960.

(C) Р.3. Мурясов, 2021 г. 